\title{
Frost weathering of chalk
}

\author{
J.B. Murton \\ University of Sussex, Brighton, $U K$
}

\begin{abstract}
The processes and factors that determine the heave and fracture of frost-susceptible bedrock exposed to temperature cycling above and below $0^{\circ} \mathrm{C}$ are little known but important to understanding of rock deformation, weathering and ground conditions. To investigate the early stages of heave, settlement and fracture of intact chalk, physical modelling experiments were performed on blocks of Saint Cyr Tuffeau and Totternhoe Clunch. Unidirectional (downward) freezing simulated seasonally frozen bedrock in non-permafrost regions, and bidirectional (upward from permafrost and downward from the surface) simulated an active layer above permafrost. Heave and settlement of the top of the blocks were monitored in relation to rock temperature and unfrozen water content.
\end{abstract}

Heave and settlement showed complex behavior that varied with moisture content, freezing regime and time. Progressive heave of wet chalk during thaw periods (simulated summers) is attributed to microcracking in near-surface permafrost. Macrocracking was favoured near the rock top during unidirectional freezing and near the permafrost table during bidirectional freezing, producing extensive fracture networks. Four processes, operating singly or in combination, account for the heave and settlement behavior: (1) thermal expansion and contraction in dry chalk; (2) volumetric expansion of freezing water, causing bursts of heave; (3) ice segregation, causing sustained heave and rock fracture; and (4) freeze-thaw cycling, causing initial consolidation and settling of wet chalk during unidirectional freezing.

The experimental data and field observations of chalk weathering profiles elucidate the nature and origin of chalk brecciation. Type 1 brecciation (angular or subangular rock fragments separated by unfilled fractures with matched sides) is attributed primarily to ice segregation. Type 2 brecciation (subangular to rounded lumps of rock-lithorelicts - set in a fine-grained matrix of the same, but softer and remoulded material) probably resulted from frost weathering and limited ground movement, particularly beneath the sides and bottoms of wet (now dry) valleys.

\section{INTRODUCTION}

Chalk weathering profiles are widespread in southern and eastern England and northwestern France. Discontinuities and/or putty-like silty clay within them substantially affect their mass hydrogeological and mechanical behavior (Younger 1989; Bell \& Culshaw 2005). Thus, characterizing, mapping and predicting the location of such weathering profiles are essential to ground investigations (Spink \& Norbury 1990). A first step to prediction is through mechanistic understanding of weathering processes.
To elucidate how frost weathering processes (Matsuoka \& Murton 2008) break up initially intact chalk, we can simulate natural freezing conditions of the ice ages using laboratory experiments. This permits monitoring and imaging of chalk deformation and fracture during multiple simulated winter and summer freeze-thaw cycles.

The aim of this article is to summarize what is known about the nature and origin of chalk weathering profiles formed by frost action. This is based on laboratory experiments, field observations and literature review. 


\section{LABORATORY EXPERIMENTS}

Two sets of laboratory experiments were performed to investigate the early stages of heave, settlement and fracture of intact (i.e. unfractured) chalk. Results from the first set (year 1 in Table 1) were reported by Murton et al. (2006, 2016); those from the second (year 2 in Table 1) are newly reported here.

\subsection{Chalk lithologies}

The criteria for selecting chalk lithologies for experimentation were (1) textural uniformity (to minimize the effects of rock structure on fracture) and (2) availability of large unfractured blocks $\left(\sim 0.5 \mathrm{~m}^{3}\right.$ size). This size was sufficient for sawing into rectangular blocks $450 \mathrm{~mm}$ high x 300 x $300 \mathrm{~mm}$ wide, allowing large-scale experiments.

Two chalks were selected: Saint Cyr Tuffeau (also known as Touraine Tuffeau) and Totternhoe Clunch. The tuffeau is a siliceous chalk with a substantial fraction of detrital quartz grains typically $\sim 100 \mu \mathrm{m}$ in diameter within a matrix of micrite and opal-cristobalite. It is of Turonian age. Samples were collected from the Lucet Quarry, Brézé-Saint-Cyren-Bourg, $10 \mathrm{~km}$ south of Saumur, France.

The Totternhoe Clunch is a coarse-grained calcarenite from the base of the Zig Zag Chalk Formation of the Grey Chalk Subgroup (Mortimore 2014). It is Middle Cenomanian in age. Samples were obtained from Totternhoe Quarry, Bedfordshire, England.

\subsection{Freeze-thaw conditions}

Unidirectional (downward) freezing of seven tuffeau blocks and one clunch block simulated seasonally frozen bedrock in non-permafrost regions. Bidirectional freezing (upward from permafrost and downward from the surface) of four tuffeau blocks and one clunch block simulated an active layer (Figure 1). Between 21 and 30 freeze-thaw cycles were performed (Table 1).

The tuffeau blocks in the year 1 experiments varied from dry (dried in a desiccator at $\sim 40{ }^{\circ} \mathrm{C}$ ) to wet (wetted by capillary rise to $\sim 86 \%$ saturation measured under vacuum) (Murton et al. 2016). The tuffeau and clunch blocks in year 2 were all wetted through by capillary rise, to maximize the water available for freezing. Saturation values recorded in the simulated active layer at the end of thaw cycles in the clunch were $61 \pm 3 \%(\mathrm{n}=14)$. Those in the clunch and tuffeau blocks subject to seasonal freezing were $70 \pm 15 \%(n=7)$ and $68 \pm 10 \%(n=17)$, respectively.

Table 1. Experimental set-up.

\begin{tabular}{llcl}
\hline & $\begin{array}{l}\text { Unidirectional } \\
\text { freezing }\end{array}$ & $\begin{array}{l}\text { Bidirectional } \\
\text { freezing }\end{array}$ & $\begin{array}{l}\text { Moisture } \\
\text { conditions }\end{array}$ \\
\hline Year 1 & $\begin{array}{l}6 \text { tuffeau*, } \\
\text { 26 cycles** }\end{array}$ & $\begin{array}{l}4 \text { tuffeau, } \\
21 \text { cycles } \\
\text { Year 2 }\end{array}$ & Dry to wet \\
& tuffeauch \& 1 & 1 clunch, & Wet \\
& 30 cycles & 24 cycles &
\end{tabular}

*Number of blocks; ** number of freeze-thaw cycles

\subsection{Instrumentation}

Heave and settlement of the top of the blocks were monitored relative to temperature and unfrozen water content at depth. On each block, heave was measured with a linear variable differential transformer, volumetric unfrozen water content with capacitance probes, and temperature with platinum resistors (Figure 1). Details are given in Murton et al. (2016).

Heave and temperature were measured automatically at one-hour intervals, and water content was measured manually at intervals of some days for more than a year in each set of experiments.

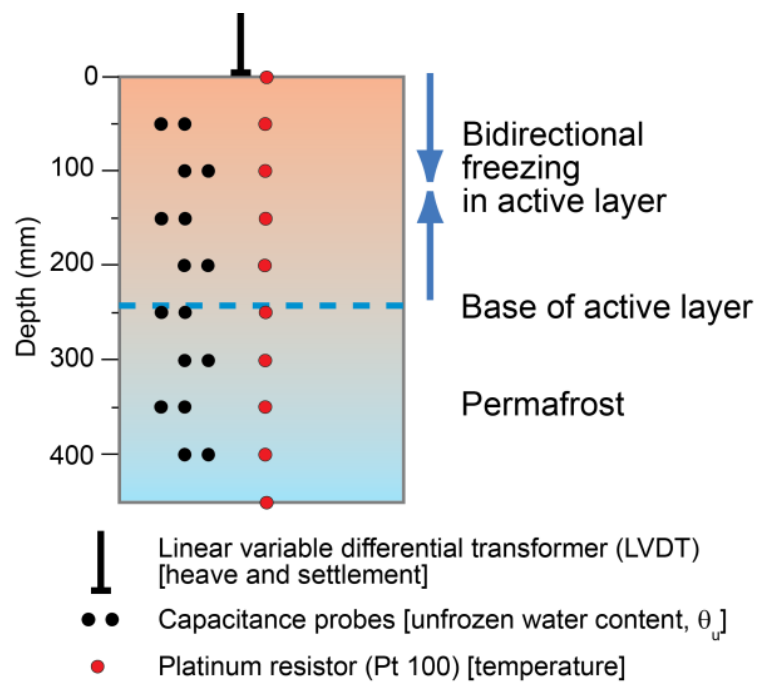

Figure 1. Diagram of experimental set-up, showing location of sensors in a chalk block subject to bidirectional freezing, simulating an active layer above permafrost. 


\subsection{Heave and settlement}

Heave and settlement time series from representative cycles of bidirectional freezing of a wet tuffeau block in the year 1 experiments are shown in Figure 2. Several features emerge.

A Stage 1. Pre-macrocracking

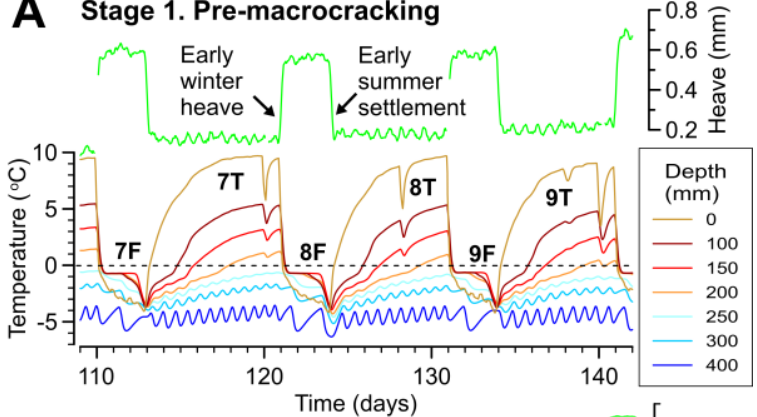

B Stage 2. Macrocracking
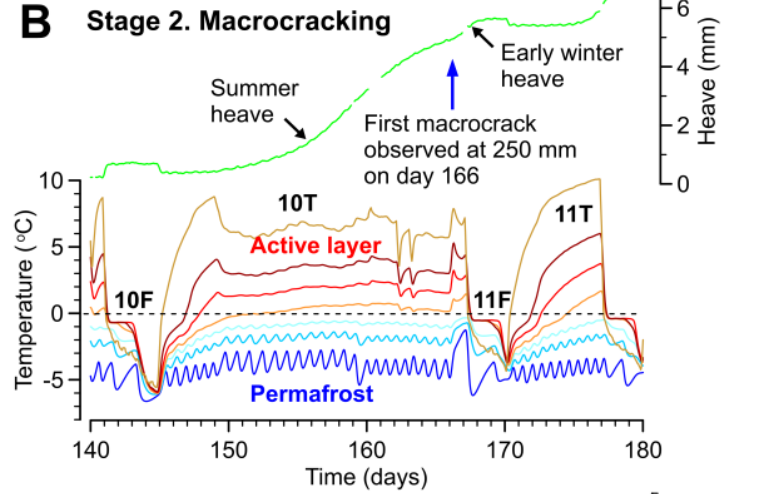

C Stage 2 continued

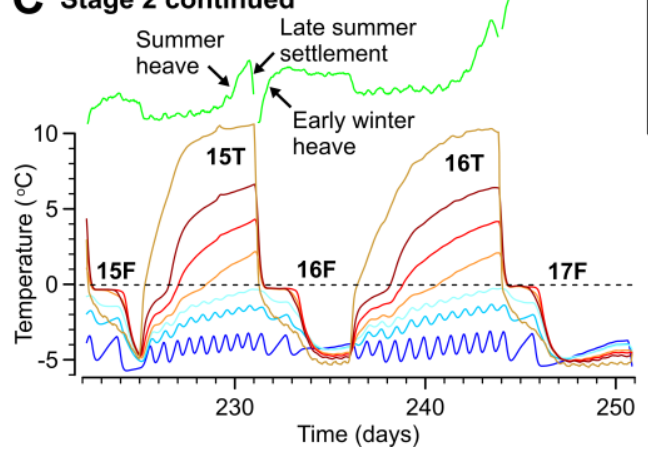

Figure 2. Time series of temperature at different depths and surface heave of a wet block of tuffeau during freeze-thaw cycles that simulate an active layer above permafrost. '7F', '7T' etc. indicate freezing period ('winter') 7 and thawing period ('summer') 7. Brown, orange and red colours denote temperature in active layer, blue colours permafrost. Modified from Murton et al. (2016).
First, short, abrupt episodes of heave and settlement at the start and end of freezing periods can be interpreted as rapid freezing/melting of in situ pore water (Figure 2A). Second, sustained gradual heave during the mid to late stages of thaw cycles (when the active layer was largely thawed and temperature conditions were steady; e.g. day 160 in Figure 2B) resulted from ice segregation in near-surface permafrost. Third, abrupt and intermittent episodes of settlement in late summer (Figure 2C) record melting of segregated ice lenses at or near the top of permafrost. Fourth, net heave of more than $10 \mathrm{~mm}$ occurred during the course of 21 freeze-thaw cycles, as segregated ice accumulated in the near-surface permafrost.

In contrast, dry blocks of tuffeau tended to settle during freezing periods and heave during thawing periods (not shown), which was clearest under unidirectional freezing. Such behavior is attributed to thermal expansion (during summer) and thermal contraction (during winter) in the absence of water-ice phase change.

With unidirectional freezing, two wet blocks of tuffeau settled progressively during the first 15 or so freeze-thaw cycles. Such behaviour was reversed during later cycles, as the blocks heaved progressively until the end of the experiment. The settlement is attributed to freeze-thaw-induced consolidation as cryosuction drew unfrozen water from the finest pores towards freezing sites, increasing effective stress in those parts of the rock below the freezing from which water was drawn (Murton et al. 2016). Freeze-thaw consolidation is well known from freezing of saturated fine-grained soils and mine tailings (e.g. Dawson et al. 1999).

\subsection{Fracture}

Macrocracks developed in blocks of wet tuffeau and clunch subject to uni- or bidirectional freezing (Figures 3 and 4). Most cracks were horizontal to subhorizontal, delimiting angular and tabular fragments of rock, though some cracks were vertical to steeply dipping. The cracks were first observed in the blocks at about the time when summer heave in the order of millimetres commenced (Figure 2B), consistent with rapid growth of segregated ice lenses in macrocracks newly formed by coalescence of microcracks. 


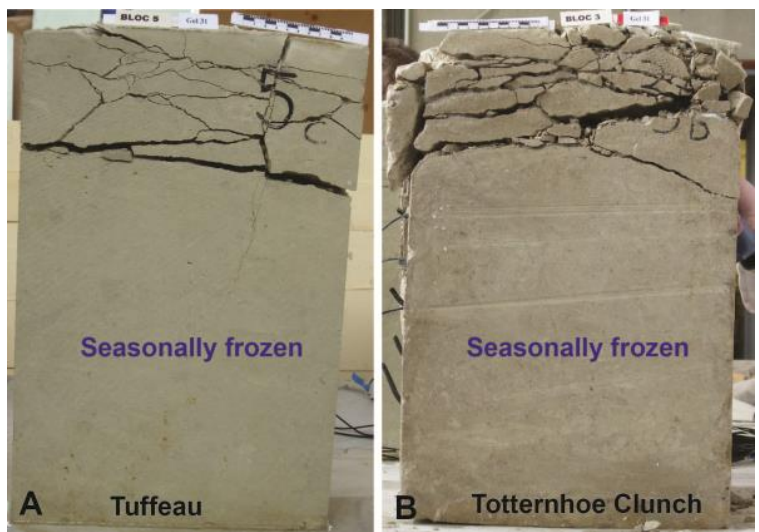

Figure 3. Photographs of fractured frozen blocks of (A) tuffeau and (B) clunch after 30 cycles of freezing and thawing in the absence of permafrost, respectively. Segregated ice, some of which has melted out, partially fills the cracks. Both blocks were initially $450 \mathrm{~mm}$ high.
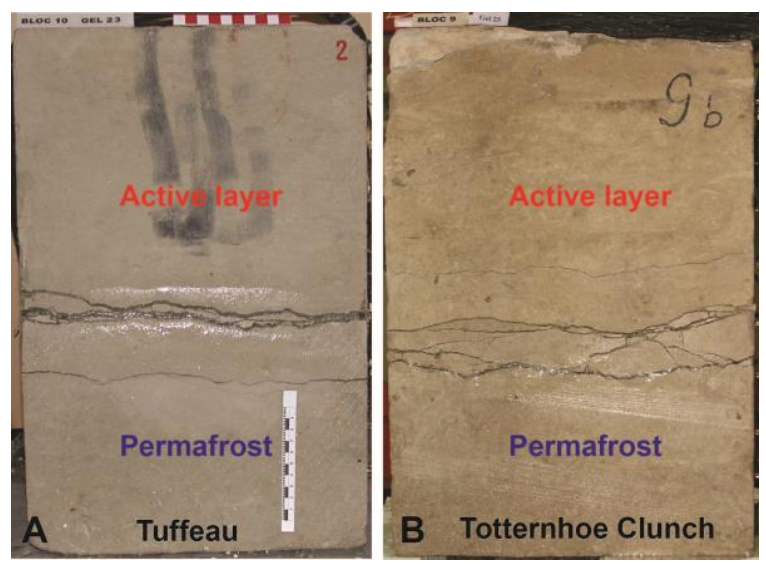

Figure 4. Photographs of fractured frozen blocks of (A) tuffeau and (B) clunch after 21 and 24 cycles, respectively, of active-layer freezing and thawing above permafrost. Segregated ice fills the cracks. Both blocks were initially $450 \mathrm{~mm}$ high.

The freezing regime influenced the depth of fracture. Unidirectional freezing favoured cracking in the upper third of the blocks (Figure 3), as cryosuction focused ice segregation there. Bidirectional freezing, in contrast, favoured cracking in the upper part of the permafrost and base of the active layer (Figure 4), as upward freezing from the permafrost table focused ice segregation in the middle of the blocks. By the end of the experiments, substantial amounts of segregated ice, visible within the cracks, had accumulated in the near-surface permafrost.

\section{FIELD OBSERVATIONS}

Field observations reveal that fractures tend to be most abundant within the upper metres of chalk in England and France (Figure 5; Williams 1987; Murton 1996). These observations can be placed in geological and geomorphological context through a landsystems approach that distinguishes plateau and valley landsystems (Figure 6; Murton \& Ballantyne 2017).

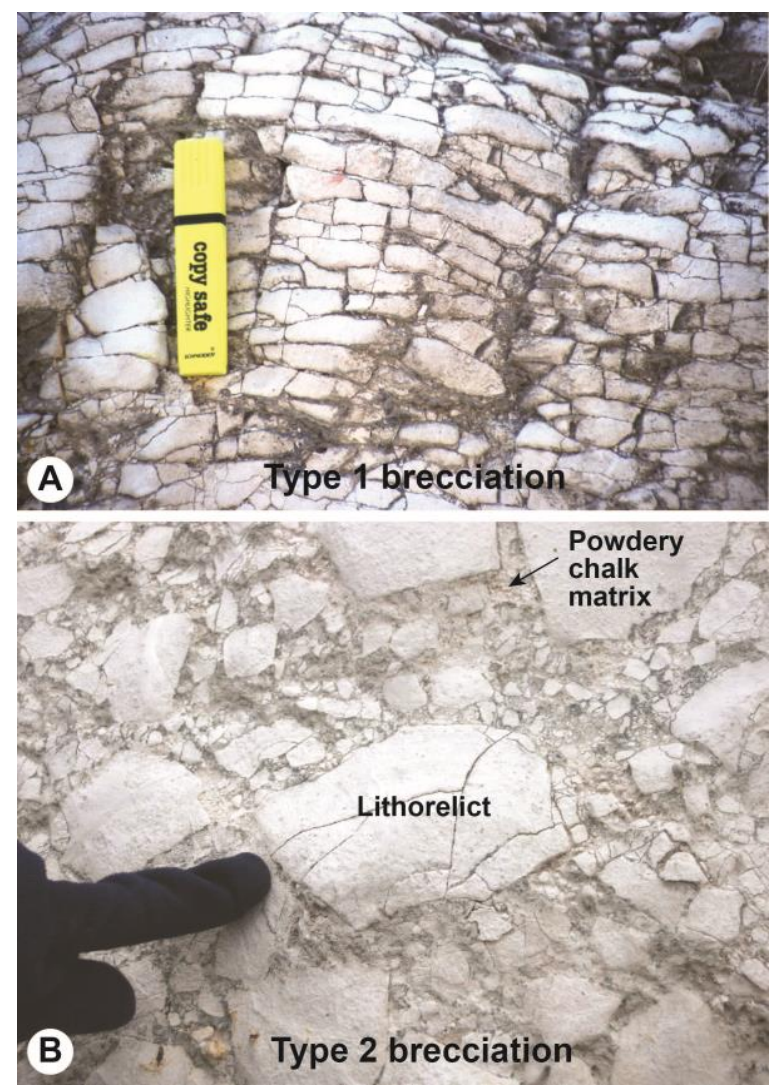

Figure 5. Photographs of brecciation within the Margate Chalk Member on Thanet, east Kent. (A) Type 1 brecciation ('structured' chalk) at $1.5-1.7 \mathrm{~m}$ depth, Foreness Point. (B) Type 2 brecciation ('destructured' chalk) adjacent to the eastern side of an infilled dry valley, Pegwell Bay. Source: Murton and Giles (2016). 


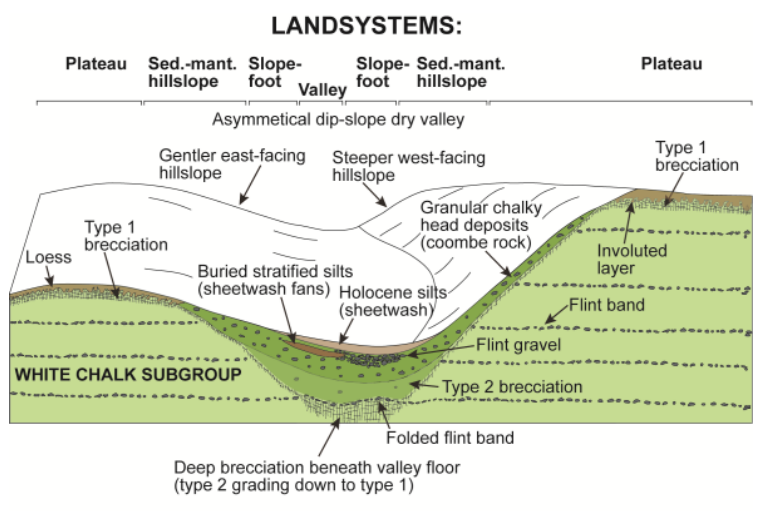

Figure 6. Landsystems associated with a large chalkland dry valley incised into a plateau, showing typical location of types 1 and 2 brecciation. Four landsystems shown. 'Sed.-mantled hillslope' denotes 'sediment-mantled hillslope landsystem. Modified from Mortimore (2014) and Murton and Ballantyne (2017).

\subsection{Plateaux}

Plateau landsystems - which include the chalk cuestas and plateaux of southern England - are characteristically underlain by type 1 brecciation (Figure 5A). This comprises angular or sub-angular rock fragments separated by unfilled fractures with matched sides. Fractures tend to be horizontal to subhorizontal, increase in spacing as depth increases, and define rock blocks that are commonly tabular and parallel to the surface. Type 1 brecciation typically forms a layer $\sim 1.5 \mathrm{~m}$ to a few metres thick. It can be described in engineering geology terms as grade B of the CIRIA (Construction Industry Research and Information Association) scheme (where fractures are open $<3 \mathrm{~mm}$ ) to grade $\mathrm{C}$ (fractures open $>3 \mathrm{~mm}$ ) (Lord et al. 2002). Thus, the fractured chalk is structured (Spink \& Norbury 1990; Spink 2002).

\subsection{Dry valleys}

Valley landsystems - typified by chalkland dry valleys incised into plateaux and cuestas - are characteristically underlain by type 2 brecciation (Figure 5B). This brecciation is texturally a diamicton with subangular to rounded lumps of rock (lithorelicts) set in a fine-grained matrix of the same, but softer and remoulded material. Type 2 brecciation contains gently folded flint bands at Birling Gap (East Sussex), and underlies Palaeogene deposits at Redcliff Point, Pegwell Bay (Kent) (Figure 7). In engineering geolo- gy terms this brecciation can be described as destructured chalk, CIRIA grade D (Spink \& Norbury 1990; Spink 2002). Clast-dominated (Grade Dc) chalk is identified where the volume of comminuted chalk matrix is $<35 \%$ of the total volume, whereas matrixdominated (Grade Dm) chalk contains $>35 \%$ matrix ('putty chalk' of Younger 1989).

Types 1 and 2 brecciation may coexist within single stratigraphic sections, with gradations between these end members. Coastal cliffs in Kent and Sussex commonly show that type 1 brecciation beneath interfluves grades upward into type 2 brecciation in the uppermost chalk. Additionally, type 1 brecciation beneath interfluves and dry valley sides may grade laterally into type 2 brecciation beneath or beside valley floors, as well exposed at Pegwell Bay.

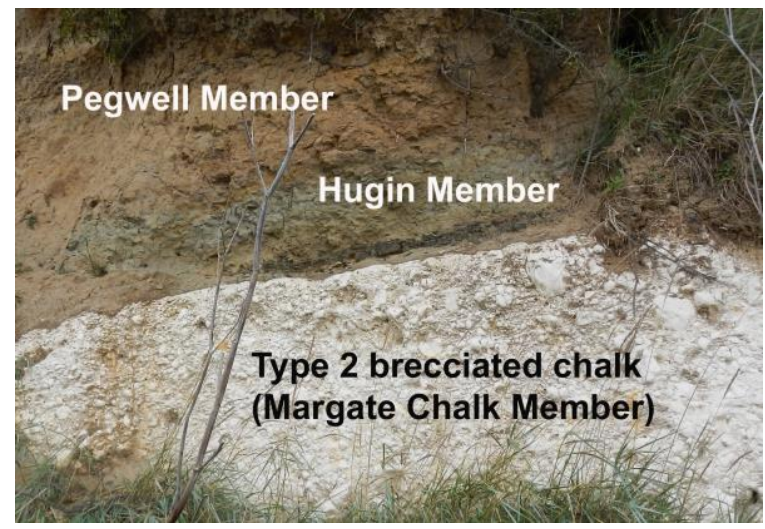

Figure 7. Photograph of contact between brecciated chalk of the Margate Chalk Member and overlying Hugin and Pegwell members of the Palaeogene Thanet Member, Redcliff Point, Pegwell Bay, east Kent. Section is about $4 \mathrm{~m}$ high. Source: Murton and Giles (2016).

\section{DISCUSSION}

The experimental data and field observations elucidate the nature and origin of chalk brecciation by frost action. Type 1 brecciation is attributed mainly to ice segregation associated with seasonal and/or perennial (permafrost) freezing. Similar brecciation is observed today in Arctic regions in near-surface permafrost developed in fine-grained sedimentary rocks (e.g. French et al. 1986).

Type 2 brecciation probably resulted from frost weathering and limited ground movement, particular- 
ly beneath the sides and bottoms of wet (now dry) valleys (Murton \& Giles 2016). Experiments subjecting chalk to multiple freeze-thaw cycles, as occur in active layers, tend to comminute chalk into finegrained debris (Lautridou \& Ozouf 1982) that comprises silt-clay chalk matrix and contains chalk fragments (lithorelicts). Such type 2 brecciation probably represents a stage of frost weathering beyond that which produces type 1 brecciation, because the former involves many more freeze-thaw cycles than the latter, and the number of cycles in periglacial regions tends to increase towards the ground surface. Heave and/or settlement structures (e.g. folded flint bands; Figure 6) within type 2 brecciation indicate local ground movement. This interpretation suggests that the Palaeogene Thanet Member at Redcliff Point (Figure 7) may have moved a little.

\section{CONCLUSIONS}

The following conclusions are drawn:

1. Ice segregation rather than volumetric expansion is the dominant process by which frost fractures wet chalk.

2. Freezing regime influences facture depth.

3 . Under periglacial conditions, valleys were wetter than interfluves, concentrating rainwater and meltwater from snow, and therefore favouring ice segregation, frost heave and thaw consolidation beneath valleys.

4. Brecciation styles of chalk are strongly influenced by landsystem position and freezing history, which permits some degree of prediction of weathering grade for developing conceptual ground models.

\section{ACKNOWLEDGEMENT}

The laboratory experiments were funded by the Natural Environmental Research Council (grant NER/A/S/2001/00506) and conducted in cold rooms of the National Center for Scientific Research (CNRS) at Caen, France. J.-C. Ozouf is thanked for discussions of the experiments, and T. Cane, G. Guillemet, B. Jackson and P. Simmons are thanked for providing technical support. The reviewers and editor
(F. Descamps) are thanked for their helpful comments.

\section{REFERENCES}

Bell, F. \& Culshaw, M. 2005. Chalk landscapes. In Geomorphology for Engineers, Fookes, P.G. Lee, E.M. \& Milligan, G. (Eds.), Whittles Publishing, Caithness, pp. 729-756.

Dawson, R.F., Sego, D.C. \& Pollock, G.W. 1999. Freeze-thaw dewatering of oil sands fine tails. Canadian Geotechnical Journal 36, pp. 587-598.

French, H.M. Bennett, L. \& Hayley, D.W. 1986. Ground ice conditions near Rea Point and on Sabine Peninsula, eastern Melville Island. Canadian Journal of Earth Sciences 23, pp. 1389-1400.

Lautridou, J.P. \& Ozouf, J.C. 1982. Experimental frost shattering: 15 years of research at the Centre de Géomorphologie du CNRS. Progress in Physical Geography 6, pp. 215-232.

Lord, J.A. Clayton, C.R.I. \& Mortimore, R.N. 2002. Engineering in Chalk. Construction Industry Research and Information Association (CIRIA), London, Publication C574.

Matsuoka, N. \& Murton, J.B. 2008. Frost weathering: recent advances and future directions. Permafrost and Periglacial Processes 19, pp. 195-210.

Mortimore, R.N. 2014. Logging the Chalk. Whittles, Dunbeath.

Murton, J.B. 1996. Near-surface brecciation of Chalk, Isle of Thanet, southeast England: a comparison with ice-rich brecciated bedrocks in Canada and Spitsbergen. Permafrost and Periglacial Processes 7, pp. 153-164.

Murton, J.B. Peterson, R. \& Ozouf, J-C. 2006. Bedrock fracture by ice segregation in cold regions. Science 314, pp. 1127-1129.

Murton, J.B. \& Giles D.P. 2016. The Quaternary Periglaciation of Kent. Field Guide. Quaternary Research Association, London.

Murton, J.B. Ozouf, J-C. \& Peterson, R. 2016. Heave, settlement and fracture of chalk during temperature cycling above and below $0^{\circ} \mathrm{C}$. Geomorphology 270, pp. 71-87.

Murton, J.B. \& Ballantyne, C.K. 2017. Periglacial and permafrost ground models for Great Britain. In Engineering Geology and Geomorphology of Glaciated and Periglaciated Terrains - Engineering Group Working Party Report, Griffiths, J.S. \& Martin CJ (eds). Geological Society, London, Engineering Group Special Publications, 28, pp. 501-597.

Spink, T.W. \& Norbury, D.R. 1990. The engineering geological description of chalk. In Proceedings of the International Chalk Symposium, Brighton. Thomas Telford Press, London, pp. 153159.

Spink, T.W. 2002. The CIRIA Chalk description and classification scheme. Quarterly Journal of Engineering Geology and Hydrogeology 35, pp. 363-369.

Williams, R.B.G. 1987. Frost weathered mantles on the Chalk. In Periglacial Processes and Landforms in Britain and Ireland, Boardman, J. (Ed.). Cambridge University Press, Cambridge, pp. 127-133.

Younger, P.L. 1989. Devensian periglacial influences on the development of spatially-variable permeability in the Chalk of southeast England. Quarterly Journal of Engineering Geology 22, pp. 343-354. 